\title{
Oral manifestations, salivary flow rates and Candida species in Thai HIV-infected patients
}

\author{
Aroonwan Lam-ubol ', Sorasun Rungsiyanont ${ }^{1}$, Piamkamon Vacharotayangul 1, Kraisorn Sappayatosok ${ }^{2}$, \\ Oitip Chankanka ${ }^{3}$
}

\author{
${ }^{1}$ Faculty of Dentistry, Srinakharinwirot University, 114 Sukhumvit 23, Wattana, Klongtoey Nua, Bangkok 10110, Thailand \\ ${ }^{2}$ Faculty of Dentistry, Rangsit University, 52/347 Phaholyothin Road, Mueang Pathum Thani District, Pathum Thani 12000, Thai- \\ land \\ ${ }^{3}$ Faculty of Dentistry, Prince of Songkla University, 15 Karnjanavanich Raod, Hat Yai, Songkhla 90110, Thailand
}

Correspondence:

Department of Oral Surgery and Oral medicine

Faculty of Dentistry

Srinakharinwirot University, Sukhumvit 23

Wattana, Bangkok 10110, Thailand

aroonwan@gmail.com

Lam-ubol A, Rungsiyanont S, Vacharotayangul P, Sappayatosok K, Chankanka O. Oral manifestations, salivary flow rates and Candida species in Thai HIV-infected patients. J Clin Exp Dent. 2019;11(2):e138-45. http://www.medicinaoral.com/odo/volumenes/v11i2/jcedv11i2p138.pdf

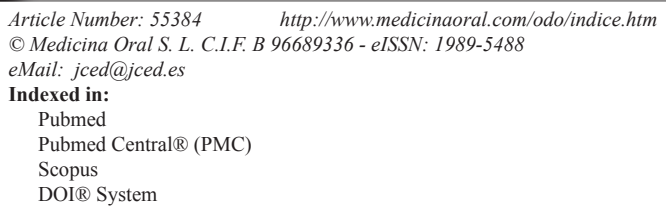

\begin{abstract}
Background: Effects of various Highly Active Antiretroviral Therapy (HAART) regimens on oral heath are unclear. Objectives: We aimed to evaluate effects of HAART on oral manifestations, salivary flow rates (SFR) and Candida species in HIV-infected patients who took mostly non-protease inhibitor-based HAART regimens.

Material and Methods: A cross-sectional study was performed on HIV-infected patients taking and never taken HAART who attended Thai Red Cross AIDS Research Centre $(n=48)$. Non-HIV subjects were recruited as control $(\mathrm{n}=20)$. Oral conditions and salivary flow rates were evaluated using oral examination and measurement of unstimulated and stimulated saliva. In addition, Candida colonization counts (colony forming units; CFUs) and Candida species from the collected saliva were evaluated using CHROMagar.

Results: The most common oral manifestation in HIV-infected subjects taking HAART was hyperpigmentation. Unstimulated and stimulated SFR among the three groups were not statistically significant. Candida colonization was detected in $64 \%, 65 \%$ and $35 \%$ of HIV-infected subjects taking HAART, HAART-naïve, and non-HIV subjects, respectively. While $20 \%$ and $35 \%$ of HIV-infected subjects with and without HAART, respectively, had Candida CFUs higher than 500/ml, all non-HIV carriers had Candida CFUs lower than 500/ml. The most common Candida colonization species was $C$. albicans in HAART and non-HIV groups. Interestingly, HAART-naïve group was colonized more by non-albicans species.

Conclusions: HAART has minimal effects on oral health. While HAART may not prevent Candida colonization, it might lead to reduction of non-albicans species. Because maintaining low Candida counts is important, HAART administration and antifungal sensitivity test should be considered in HIV-infected patients.
\end{abstract}

Key words: HIV, Candida, HAART, Oral manifestation, Salivary flow rates. 


\section{Introduction}

Human Immunodeficiency Virus (HIV) infection has been one of the major public health problems. According to UNAIDS, it was estimated that 36.9 million people were living with HIV worldwide in 2017. Although HIV infection caused high mortality and morbidity in the past, the disease has been better controlled since the introduction of Highly Active Antiretroviral Therapy (HAART) in 2000 (1-3). HIV-infected patients are now living longer. Trends of diseases have been changed with significant decrease in opportunistic infections. However, patients living with AIDS face other health problems such as lipodystrophy, cardiovascular diseases and cancers, due to the disease itself and side effects from HAART (4). Oral side effects of HAART have been reported, such as hyperpigmentation, salivary gland hypofunction, salivary gland enlargement and human papillomavirus infection $(1,5)$. Since then, there have been changes in HAART regimen to maximize antiviral effects and minimize adverse effects. Non-nucleoside reverse transcriptase inhibitor (NNRTI)-containing regimens offer superior virological suppression and better immunological outcome than protease-inhibitor (PI)-containing regimens $(2,6,7)$. Most current first line regimens worldwide, including Thailand, had shifted from PI-containing regimens to NNRTI-containing regimens $(1,2,8,9)$.

Oral candidiasis, one of the most common opportunistic infection in HIV-infected patients, has been significantly reduced with HAART (1-3). Effects of HAART on Candida colonization in HIV-infected patients is still controversial (8-10). Although Candida species can normally colonize in the oral cavity without clinical symptoms, increased numbers of Candida colonization had been shown to promote risk of oral candidiasis $(11,12)$. Oral cavity colonization by Candida species can be found in healthy population, however, percentage of Candida carriers in HIV-infected patients were reported to be higher than in healthy population (8). Candida albicans is the most common species found in oral candidiasis and Candida colonization in HIV-infected subjects. However, there has been an increase in non-albicans species in this population (13-15). PIs were shown to have inhibitory effects against Candida (16). However, NRTIs and NNRTIs are used more frequently nowadays. Previous studies showed inconsistent results about incidences in developing oral candidiasis between NNRTI-users and PI-users $(2,17)$. In addition, effects of HAART on Candida colonization and Candida species were unclear.

\section{Objectives}

Studies on effects of HAART on oral changes, Candida species and salivary gland function had been reported from several countries, including Thailand, with various results $(1,18)$. These could be because differences in study population, HAART regimens and study methods. The objective of this study was to evaluate effects of HAART on oral manifestations, Candida colonization species and salivary flow rates in Thai HIV-infected patients.

\section{Material and Methods}

-Study design and participants

This was a cross-sectional study performed in patients infected with HIV who attended the Thai Red Cross AIDS Research Centre. Both patients receiving HAART and never received HAART (HAART-naïve) were recruited. In addition, control group included non-HIV-infected subjects recruited from the Faculty of Dentistry, Srinakharinwirot University, Bangkok, Thailand. The study protocol was approved by the ethical review boards of the Faculty of Medicine, Chulalongkorn University and Faculty of Dentistry, Srinakharinwirot University. All subjects were informed of the objectives and study protocol, and gave written consent prior to participate in the study. All non-HIV-infected subjects received blood test to confirm HIV-seronegativity. Subjects who had oral candidiasis or systemic or local treatment with antifungals within the previous three months were excluded from the study.

-Data collection

The following data were collected from the HIV-infected subject's medical records: personal information, medical history and results from laboratory tests (the closest ones to the time of sample collection), CD4 counts, viral load, diagnosis of AIDS, antiretroviral therapy, and use of antifungal or other medication. Subjects were instructed not to eat or drink for one hour prior to sample collection. Subjects were then interviewed regarding dental problems. Oral and dental structures were examined and recorded by oral medicine specialists. Un-stimulated and mechanical-stimulated saliva samples were collected by using standard protocol. For un-stimulated saliva, the subjects were asked to rinse their mouth with water. Then, after swallowing all the saliva present in the mouth, they were instructed to allow new saliva to accumulate in the mouth, and expectorate it into a $50 \mathrm{ml}$ tube that was previously weighed every 60 seconds for a period of 5 minutes. For stimulated saliva, subjects were asked to chew on a piece of paraffin (1 gram) and expectorate whole stimulated saliva into a $50 \mathrm{ml}$ tube for 5 minutes. Salivary flow rates were calculated as $\mathrm{ml} / \mathrm{min}$. After collection, the saliva was kept at 4 degrees Celsius and used for analysis within 6 hours.

-Analysis of Candida counts and species

The saliva samples were centrifuged and supernatants were used for the analysis. Each saliva sample was diluted 1:10 with phosphate buffered saline $\mathrm{pH} 7.2$ and cultured on CHROMagar Candida plates (CHROMagar Microbiology) in an incubator at 37 degrees Cel- 
sius. Colony forming units (CFUs) and colony color and morphology were evaluated after 48 hours. CFUs were classified as low (less than $500 \mathrm{CFUs} / \mathrm{ml}$ ) and high (more than $500 \mathrm{CFUs} / \mathrm{ml}$ ). Candida colonies were characterized based on color according to the manufacturer's recommendation ( $C$. albicans: green, $C$. tropicalis: metallic blue, $C$. krusei: pink, fuzzy, other species: white to mauve). Plates exhibiting no growth were incubated for another 24 hours to confirm the absence of Candida colonies.

-Statistical analysis

Demographic data and salivary flow rates of HIV-infected subjects taking HAART, HIV-infected subjected not taking HAART (HAART-naïve) and non-HIV-infected subjects were compared using Independent Sample Kruskal-Wallis test, Mann-Whitney U test or Chi-square as specified.

\section{Results}

-Demographic data of the study population A total of sixty-eight subjects were included in the study. Twenty-five $(36.8 \%)$ and $23(33.8 \%)$ of them were HIV-infected patients who received HAART and HAART-naïve, respectively. Twenty (29.4\%) non-HIV-infected subjects were included as control group.

Average age and sex of subjects in the three groups were not statistically significant (Table 1). Duration of HIV infection ranged from 2 to 18 years with an average of 8.5 years in a group taking HAART and 6.7 years in a HAART-naïve group. Average CD4 counts in a HIV-infected groups taking HAART and HAART-naïve were $513+193$ and $425+183$ cells per $\mathrm{ml}$, respectively. Although CD4 counts in HAART-naïve group were significantly lower $(p=0.03)$, all subjects had CD4 counts more

Table 1: Demographic data of study population.

\begin{tabular}{|c|c|c|c|c|}
\hline & $\begin{array}{l}\text { HIV with } \\
\text { HAART }\end{array}$ & HIV, HAART-naïve & Non-HIV & $P$-value \\
\hline Numbers & 25 & 23 & 20 & \\
\hline $\begin{array}{c}\text { *Age } \\
\text { (range, average+SD) }\end{array}$ & $28-47,36.6 \pm 4.7$ & $\begin{array}{c}22-49 \\
33.8+5.8\end{array}$ & $\begin{array}{c}20-53 \\
35.6 \pm 7.8\end{array}$ & 0.139 \\
\hline $\begin{array}{c}* * * \text { Sex (numbers, \%) } \\
\text { Male } \\
\text { Female }\end{array}$ & $\begin{array}{r}6,24 \% \\
19,76 \% \\
\end{array}$ & $\begin{array}{l}8,35 \% \\
15,65 \%\end{array}$ & $\begin{array}{l}6,30 \% \\
14,70 \% \\
\end{array}$ & 0.765 \\
\hline $\begin{array}{c}* * \mathrm{CD} 4(\text { cells } / \mathrm{ml}) \\
\text { (range, average } \_ \text {SD) }\end{array}$ & $\begin{array}{c}247-1156 \\
513 \pm 193\end{array}$ & $\begin{array}{l}203-798 \\
425 \pm 183\end{array}$ & $\mathrm{n} / \mathrm{a}$ & 0.030 \\
\hline $\begin{array}{l}\text { Less than } 200 \\
201-500 \\
\text { more than } 500\end{array}$ & $\begin{array}{c}0 \\
13,52 \% \\
12,48 \%\end{array}$ & $\begin{array}{c}0 \\
16,70 \% \\
7,30 \%\end{array}$ & & \\
\hline $\begin{array}{l}\text { Viral load (copies per ml) } \\
\quad(\text { range, average+SD) }\end{array}$ & Less than 40 & $\begin{array}{c}80-64653 \\
16285 \pm 21979\end{array}$ & 0 & - \\
\hline $\begin{array}{c}\text { Less than } 40 \\
41-50,000 \\
\text { More than } 50,000\end{array}$ & $25,100 \%$ & $\begin{array}{c}0 \\
21,91 \% \\
2,9 \%\end{array}$ & & \\
\hline $\begin{array}{l}* * \text { Years infected } \\
\text { (range, average } \pm \text { SD) } \\
\text { Less than } 5 \text { years } \\
\text { More than } 5 \text { years }\end{array}$ & $\begin{array}{c}4-18,8.5+3.5 \\
1,4 \% \\
24,96 \%\end{array}$ & $\begin{array}{c}2-10,6.7+2.5 \\
5,22 \% \\
18,78 \%\end{array}$ & $\mathrm{n} / \mathrm{a}$ & 0.117 \\
\hline $\begin{array}{c}\text { Years taken HAART (range, } \\
\text { average+SD) } \\
\text { Less than } 5 \text { years } \\
\text { More than } 5 \text { years }\end{array}$ & $\begin{array}{c}0.6-13.85 .7 \pm 2.97 \\
5,20 \% \\
20,80 \%\end{array}$ & $\mathrm{n} / \mathrm{a}$ & $\mathrm{n} / \mathrm{a}$ & - \\
\hline
\end{tabular}


than 200 cells per ml. As expected, average viral loads in HIV-naïve subjects $(16,285$ copies per $\mathrm{ml})$ were higher than HIV-infected subjects taking HAART (lower than 40 copies per $\mathrm{ml}$ ). Regarding HAART regimens, majority $(88 \%)$ of HIV-infected subjects received combination of NRTIs and NNRTIs. Only 3 HIV-infected subjects $(12 \%)$ received combination of NRTIs and PIs. Average duration of HAART usage was 5.7 years, ranging from 0.6-13.8 years. Most subjects ( $80 \%$ ) had taken HAART for longer than 5 years.

-Oral and dental findings

Oral lesions observed among HIV-infected subjects included dry mouth and hyperpigmentation. Notably $40 \%$ of subjects taking HAART demonstrated hyperpigmentation of oral mucosa, while no hyperpigmentation was found in HAART-naïve subjects. Signs of dry mouth were noted in $20 \%$ of HIV-infected subjects taking HAART and $4.3 \%$ of HAART-naïve subjects. Other lesions included aphthous ulcer, smoking-induced leukoplakia, nicotinic stomatitis, traumatic ulcer and coated tongue as shown in Table 2. Noted that these other lesions, except coated tongue, were only observed in HIV-infected subjects taking HAART. However, the numbers were low and may not be of clinical significance.
-Salivary flow rates

Unstimulated salivary flow rates in non-HIV infected subjects $(0.60+0.3 \mathrm{ml} / \mathrm{min})$ were higher than HIV-infected groups taking HAART $(0.53+0.2 \mathrm{ml} / \mathrm{min})$ and HAART-naïve $(0.48+2.2 \mathrm{ml} / \mathrm{min})$. On the other hand, stimulated salivary flow rates in HAART-naïve HIV-infected subjects $(3.11+2 \mathrm{ml} / \mathrm{min})$ were higher than nonHIV infected subjects $(2.6+1.1 \mathrm{ml} / \mathrm{min})$ and HIV-infected subjects taking HAART $(2.34+0.8 \mathrm{ml} / \mathrm{min})$. The summary of data is shown in Table 3 . However, the difference was not statistically significant.

-Candida counts and factors affecting Candida colonization Percentage of Candida carriers in HIV-infected subjects taking HAART and HAART-naïve were $64 \%$ and $65 \%$, respectively, which were higher than those in non-HIV-infected subjects (35\%). In addition, Candida CFUs in all non-HIV-infected subjects were lower than $500 \mathrm{CFUs} / \mathrm{ml}$. On the other hand, $20 \%$ of HIV-infected subjects taking HAART and 35\% of HAART-naïve subjects had CFUs more than $500 \mathrm{CFUs} / \mathrm{ml}$. The summary of data is shown in Figure 1. When we evaluated factors that might affects Candida colonization in each group, no statistically difference was found in any factors, including CD4 counts, years of HIV infections, years of HAART usage and salivary flow rates (Table 4).

Table 2: Oral manifestations in HIV-infected subjects.

\begin{tabular}{|c|c|c|}
\hline \multirow{2}{*}{ Manifestations } & \multicolumn{2}{|c|}{ Numbers, \% } \\
\cline { 2 - 3 } & HIV with HAART & HIV, HAART-naïve \\
\hline Dry mucosa & $5,20 \%$ & $1,4.3 \%$ \\
\hline Pigmentation & $10,40 \%$ & 0 \\
\hline Aphthous ulcer & $1,4 \%$ & 0 \\
\hline Smoking leukoplakia & $1,4 \%$ & 0 \\
\hline Nicotinic stomatitis & $1,4 \%$ & 0 \\
\hline Traumatic ulcer & $1,4 \%$ & $3,13 \%$ \\
\hline Coated tongue & $1,4 \%$ & \\
\hline
\end{tabular}

Table 3: Salivary flow rates (SFR) of study populations.

\begin{tabular}{|c|c|c|c|c|}
\hline & $\begin{array}{l}\text { HIV with HAART } \\
(\mathrm{N}=\mathbf{2 5})\end{array}$ & $\begin{array}{l}\text { HIV, HAART-naïve } \\
(\mathbf{N}=\mathbf{2 3})\end{array}$ & $\begin{array}{c}\text { Non-HIV } \\
(\mathbf{N}=\mathbf{2 0})\end{array}$ & $P$-value \\
\hline $\begin{array}{c}\text { *Unstimulated SFR (range, } \\
\text { average } \pm \text { SD) }\end{array}$ & $\begin{array}{l}0.22-1.15 \\
0.53 \pm 0.24\end{array}$ & $\begin{array}{l}0.16-0.99 \\
0.48 \pm 0.22\end{array}$ & $\begin{array}{c}0.11-1.22 \\
0.6 \pm 0.3\end{array}$ & 0.385 \\
\hline $\begin{array}{c}\text { Less than } 0.1 \mathrm{ml} / \mathrm{min} \\
0.1-0.2 \mathrm{ml} / \mathrm{min} \\
0.3 \mathrm{ml} / \mathrm{min} \text { and more }\end{array}$ & $\begin{array}{c}0 \\
3,12 \% \\
22,88 \%\end{array}$ & $\begin{array}{c}0 \\
6,26 \% \\
17,74 \%\end{array}$ & $\begin{array}{c}0 \\
3,15 \% \\
17,85 \%\end{array}$ & \\
\hline $\begin{array}{l}\text { *Stimulated SFR (range, } \\
\text { average } \pm \text { SD) }\end{array}$ & $\begin{array}{l}0.85-3.64 \\
2.34 \pm 0.79\end{array}$ & $\begin{array}{l}1.4-9.06 \\
3.11 \pm 2.0\end{array}$ & $\begin{array}{c}0.67-4.48 \\
2.6 \pm 1.1\end{array}$ & 0.537 \\
\hline $\begin{array}{c}\text { Less than } 0.7 \mathrm{ml} / \mathrm{min} \\
0.7-1.5 \mathrm{ml} / \mathrm{min} \\
1.5 \mathrm{ml} / \mathrm{min} \text { and more }\end{array}$ & $\begin{array}{c}0 \\
2,8 \% \\
23,92 \%\end{array}$ & $\begin{array}{c}0 \\
1,4 \% \\
22,96 \%\end{array}$ & $\begin{array}{c}1,5 \% \\
2,10 \% \\
17,85 \%\end{array}$ & \\
\hline
\end{tabular}

*Independent Sample Kruskal-Wallis test. 


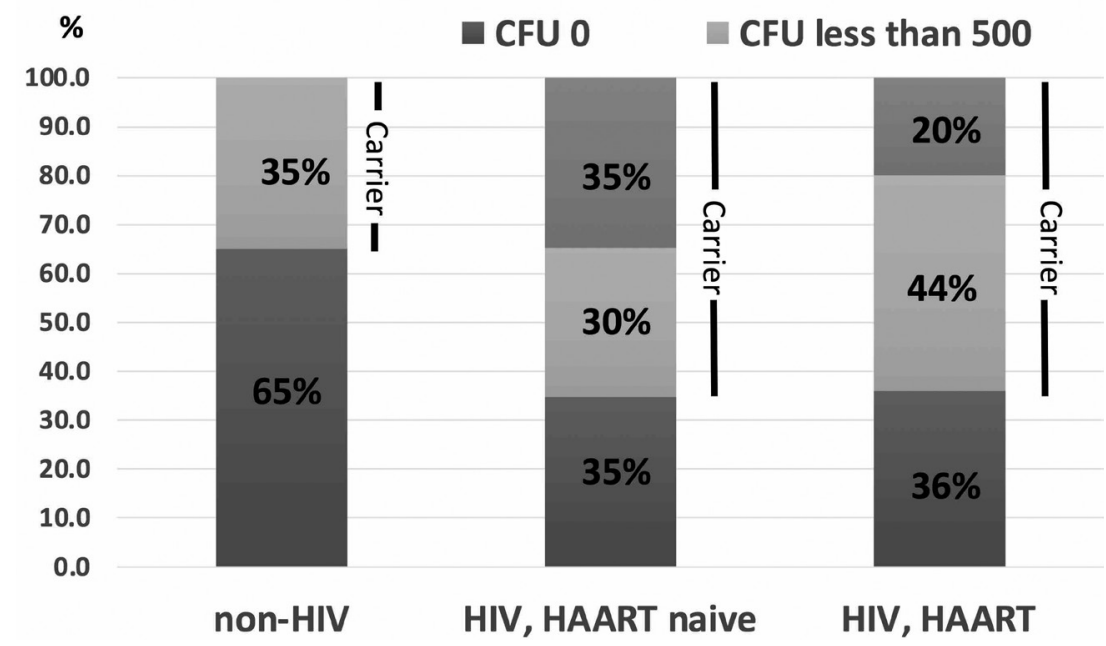

Fig. 1: Candida carriers and Candida counts in non-HIV, HIV-infected subjects who never taken and taking HAART, respectively.

Table 4: Comparisons of factors between Candida carrier and non-carriers.

\begin{tabular}{|c|c|c|c|c|c|}
\hline & \multicolumn{2}{|c|}{$\begin{array}{l}\text { HIV with HAART } \\
(\mathrm{N}=25)\end{array}$} & \multicolumn{2}{|c|}{$\begin{array}{l}\text { HIV, HAART-naïve } \\
(\mathrm{N}=23)\end{array}$} & \multirow[t]{2}{*}{$P$-value } \\
\hline & Candida carriers & Candida non-carriers & Candida carriers & Candida non-carriers & \\
\hline Numbers & 16 & 9 & 15 & 8 & \\
\hline $\begin{array}{c}* \text { Age } \\
\text { (range, average } \pm \text { SD) }\end{array}$ & $28-47,38 \pm 4.47$ & $\begin{array}{c}28-41 \\
34.2+4.3\end{array}$ & $\begin{array}{c}22-47 \\
33.8+5.4\end{array}$ & $\begin{array}{c}27-49 \\
33.8 \pm 6.9\end{array}$ & 0.060 \\
\hline $\begin{array}{c}* \mathrm{CD} 4(\text { range, } \\
\text { average }+\mathrm{SD}, \text { cells } / \mathrm{ml})\end{array}$ & $\begin{array}{c}247-1156 \\
539.2 \pm 217 \\
\end{array}$ & $\begin{array}{c}301-651 \\
461.8+127\end{array}$ & $\begin{array}{c}228-798 \\
452.4 \pm 179\end{array}$ & $\begin{array}{c}203-768 \\
378.7 \pm 196\end{array}$ & 0.091 \\
\hline $\begin{array}{l}\text { Viral load (range, } \\
\text { average+SD) }\end{array}$ & Less than 40 & Less than 40 & $\begin{array}{c}1256-64653 \\
20009 \pm 23949\end{array}$ & $\begin{array}{c}80-8343 \\
3874+4173\end{array}$ & \\
\hline $\begin{array}{c}\text { *Years infected (range, } \\
\text { average } \pm \text { SD) }\end{array}$ & $\begin{array}{c}4-18 \\
8.7 \pm 4.1\end{array}$ & $\begin{array}{c}5-11 \\
8 \pm 2.1\end{array}$ & $\begin{array}{c}4-10 \\
6.8 \pm 2.5\end{array}$ & $\begin{array}{c}2-10 \\
6.4 \pm 2.7\end{array}$ & 0.476 \\
\hline $\begin{array}{c}\text { ** Years taken HAART } \\
\text { (range, average }+\mathrm{SD} \text { ) } \\
<5 \text { years } \\
\quad>5 \text { years }\end{array}$ & $\begin{array}{c}0.6-13.8 \\
5.6 \pm 3.3 \\
4 \\
12 \\
\end{array}$ & $\begin{array}{c}1.1-9.7 \\
6.0 \pm 2.5 \\
1 \\
8\end{array}$ & $\mathrm{n} / \mathrm{a}$ & $\mathrm{n} / \mathrm{a}$ & 0.506 \\
\hline $\begin{array}{l}\text { *Unstimulated SFR } \\
\text { (range, average } \_ \text {SD) }\end{array}$ & $\begin{array}{c}0.22-1.15 \\
0.59 \pm 0.26\end{array}$ & $\begin{array}{l}0.25-0.74 \\
0.44 \pm 0.17\end{array}$ & $\begin{array}{l}0.18-0.99 \\
0.46 \pm 0.22\end{array}$ & $\begin{array}{l}0.16-0.84 \\
0.52 \pm 0.22\end{array}$ & 0.282 \\
\hline \multirow[t]{3}{*}{$\begin{array}{c}\text { *Stimulated SFR } \\
\text { (range, average } \pm \text { SD) }\end{array}$} & $\begin{array}{c}1.42-3.53 \\
2.38 \pm 0.69\end{array}$ & $\begin{array}{c}0.85-3.64 \\
2.26 \pm 0.98\end{array}$ & $\begin{array}{l}1.40-9.06 \\
3.08 \pm 1.82\end{array}$ & $\begin{array}{l}1.56-1.82 \\
3.18 \pm 2.44\end{array}$ & 0.631 \\
\hline & \multicolumn{4}{|c|}{$\begin{array}{c}\text { Non-HIV } \\
(\mathrm{N}=20)\end{array}$} & \\
\hline & \multicolumn{2}{|c|}{ Candida carriers } & \multicolumn{2}{|c|}{ Candida non-carriers } & \\
\hline $\begin{array}{l}* * \text { Unstimulated SFR } \\
\text { (range, average+SD) }\end{array}$ & \multicolumn{2}{|c|}{$\begin{array}{l}0.17-0.63 \\
0.46 \pm 0.15\end{array}$} & \multicolumn{2}{|c|}{$\begin{array}{l}0.11-1.22 \\
0.68 \pm 0.35\end{array}$} & 0.241 \\
\hline $\begin{array}{c}* * \text { Stimulated SFR } \\
\text { (range, average } \pm \text { SD) }\end{array}$ & \multicolumn{2}{|c|}{$\begin{array}{l}1.63-4.48 \\
2.86 \pm 0.88\end{array}$} & \multicolumn{2}{|c|}{$\begin{array}{l}0.67-4.44 \\
2.45 \pm 1.19\end{array}$} & 0.393 \\
\hline
\end{tabular}

* Kruskal-Wallis test

**Mann-Whitney U Test 
-Candida species

Regarding Candida species, HIV-infected subjects with HAART were colonized by $C$. albicans alone (32\%) more than mixture between albicans and non-albicans (20\%) and non-albicans alone (12\%). The profile was similar to non-HIV infected subjects who were colonized mostly by $C$. albicans alone (15\%) and mixture between albicans and non-albicans (15\%). On the other hand, majority of Candida carriers in HAART-naïve group were colonized by non-albicans alone (26\%) and mixture between albicans and non-albicans (26\%). Only $13 \%$ of them were colonized by $C$. albicans alone. All non-albicans species identified in this study demonstrated white colonies, meaning that they were other species than $C$. tropicalis and C. krusei. The summary of data is shown in Figure 2. This data suggests that HAART usage and HIV infection might affect Candida colonization profile. and has been reported $(1,19)$. Other oral lesions were few, in accordance to some previous studies $(1,19)$. Another study from Thailand showed higher percentages of oral lesions than our study. However, their subjects had higher viral load levels and lower CD4 counts than our subjects (1). One reason could be because our population received HAART early in their disease courses. This assumption is supported by recent study, which revealed that early administration of HAART when CD4 is lower than 350 cells $/ \mathrm{ml}$ reduced incidence of oral lesions when compared to late administration (when CD4 is lower than 200 cells/ml) (20). Consistent with previous study in Thailand, we did not find any wart or Human Papillomavirus (HPV)-induced lesion in this population (1). Interestingly, our previous study showed that HIV-infected individuals had higher prevalence of HPVs, especially high-risk HPVs, detected from their

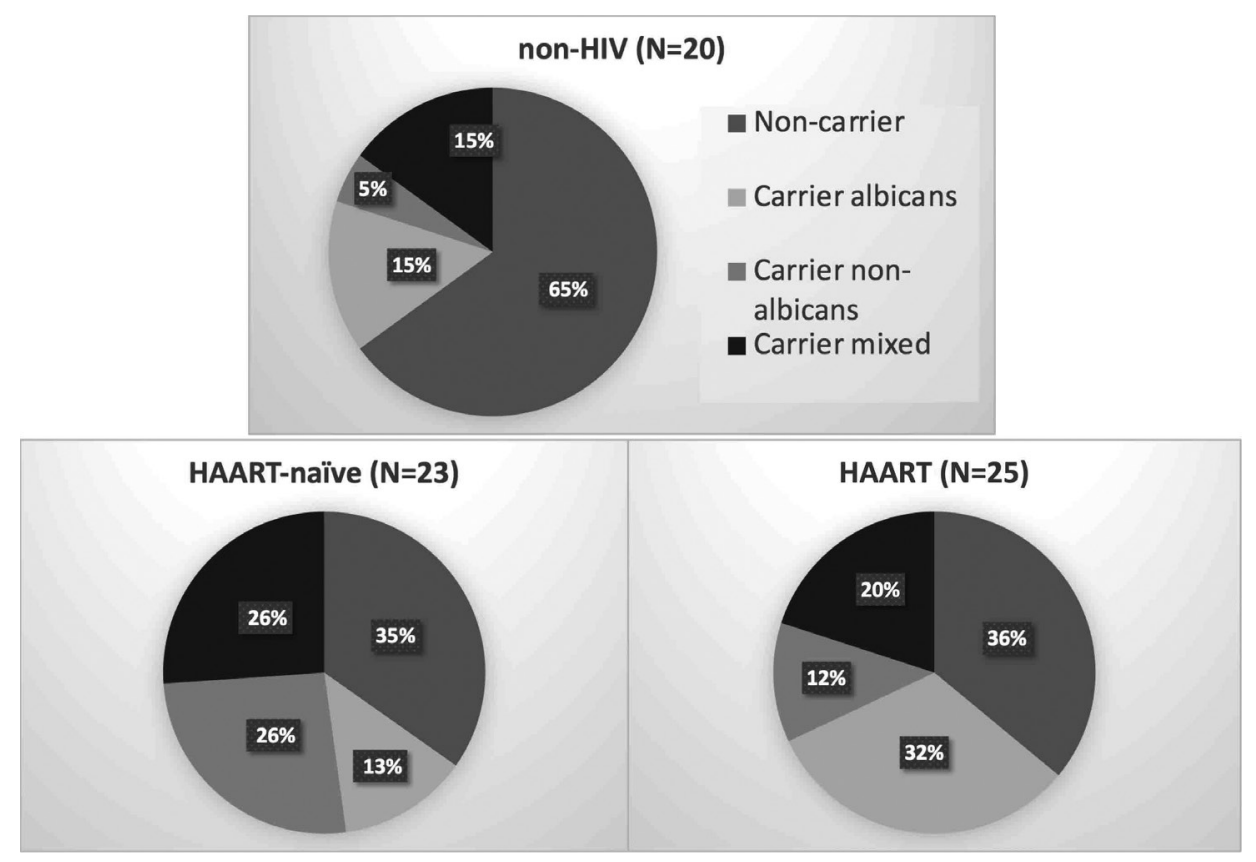

Fig. 2: Candida species colonization in non-HIV, HIV-infected subjects who never taken and taking HAART, respectively.

\section{Discussion and conclusion}

This cross-sectional study evaluated effects of HIV infection and current HAART regimen on oral conditions and Candida colonization in Thai population.

We found that current HAART regimens in majority of our population were combination of NRTIs and NNRTIs, which were different than previously used PIs. This regimen is consistently used nowadays due to reported better virological controls than PIs $(6,7)$. Similar to previous studies, we found that hyperpigmentation is common among HAART users as compared to HAART-naïve and non-HIV-infected subjects. This is not surprising, as hyperpigmentation is a known side effect of HAART oral rinses even without visible lesions (21). Long-term study for prevalence of HPV-associated lesions, including oropharyngeal cancer will be of value.

The prevalence of xerostomia and salivary gland hypofunction has been reported to be $2 \%$ to $10 \%$ in HIV infected patients $(5,22)$. In addition, previous studies show that PIs led to significant effect on salivary gland function $(4,5)$. On the other hand, continue treatment with non-PI HAART will improve salivary flow rates $(5,23)$. We noted that percentage of HAART users with signs of dry mouth was not different from that of HAART-naïve $(24 \%$ vs $17.3 \%)$. Moreover, salivary flow rates were not statistically different among the three groups. In our 
study, none of HIV-infected subjects had hyposalivation (less than $0.1 \mathrm{ml} / \mathrm{min}$ for unstimulated salivary flow rate and less than $0.7 \mathrm{ml} / \mathrm{min}$ for stimulated salivary flow rate). This could be because majority of subjects were long-term users of non-PI-based HAART regimens. Consistent with previous studies, this HAART regimen seems to have little effects to salivary gland function $(5,23)$. However, study by the other group in Thailand showed that salivary flow rates of HAART users were significantly lower than non-HAART users (1). This could be due to differences in saliva collection, HAART regimen and study population. In addition, some of their population had CD4 levels lower than 200 cells/ml, which had been reported to affect salivary gland function in HAART users $(1,24)$.

Our study showed that HIV-infected subjects had higher percentage of Candida carriers and Candida counts, regardless of HAART status. Percentages of Candida carriers in our study were $64 \%$ and $65 \%$ in HIV-infected subjects taking and not taking HAART, respectively. On the other hand, $35 \%$ of Candida carriers were detected in healthy control group. In addition, Candida colonization CFUs in HIV-infected subjects were higher than those in healthy subjects. The findings were similar to previous studies which demonstrated that Candida carriers in HIV-infected subjects ranged from 42-57\% $(8,9,15)$. Previous study in Thailand reported $56.6 \%$ Candida carriers in HIV-infected subjects (9). Previous studies have shown that HAART decreased the incidence of all HIV-related opportunistic infections including fungal infection, but there are conflicting reports regarding the association between oral yeast colonization and HAART. While some studies, including ours, showed no protective effects of HAART on Candida colonization, some studies reported decreased in Candida colonization in HAART users, particularly those with PI-based regimens $(8-10,14,17)$. These could be due to differences in study population, HAART regimen and fungal identification methods.

While antifungal mechanism of PIs, due to its ability to inhibit fungal secretory aspartyl proteinases (16), is well-known, that of non-PI-based HAART is not clearly understood. Because CD4 levels lower than 200 cells $/ \mathrm{ml}$ were one of the risk factors of Candida colonization, antifungal ability of non-PI-based HAART could be indirectly due to restoration of CD4 levels (15). In our study, although CD4 levels of subjects in HAART-naïve group were significantly lower than those in HAART group, all population had CD4 levels higher than 200 cells $/ \mathrm{ml}$. This could explain why we did not see effect of HAART on Candida colonization in our population. Table 5 reveled that salivary flow rates and other factors did not affect Candida colonization. Other factors might affect -Candida colonization in our population.

Candida colonization profile observed in our study was similar to other studies. Studies in many countries, including Brazil, Thailand, China, demonstrated that $C$. albicans was the most common species in both healthy and HIV-infected Candida carriers. Variety of non-albicans species had been detected in HIV-infected Candida carriers from $20 \%$ to $50 \%(8,9,25)$. In addition, mixed colonization had been identified from $7 \%$ to $41 \%(8,9)$. Percentage of Candida species colonization from our findings were within the ranges previously reported. Interestingly, colonization by non-albicans and mixed species were observed in healthy subjects. Similar findings were also previously described $(8,9)$.

Risk factors for non-albicans colonization are controversial and include reduced CD4 counts (less than 200 cells/ml), use of antibiotics and antifungal drugs, history of tuberculosis, contraceptive use and HIV infection $(9,26,27)$. In our study, HAART-naïve HIV-infected subjects were colonized more by non-albicans species. This study showed that although the use of HAART did not reduce Candida colonization and Candida counts, it led to reduction of non-albicans colonization. This was in accordance with previous studies that NRTIs and NNRTIs also had antifungal activity with unknown mechanism $(2,7)$. In addition to antifungal effects of HAART, restoration of CD4 levels might contribute to the reduction of non-albicans colonization (26).

Although the role of non-albicans and mixed Candida colonization in HIV-infected individual is not clear, non-albicans species were shown to be more resistant to conventional antifungal drugs $(28,29)$. In addition, mixed infection may make drug resistance more complicated (30). Due to the limited availability of data, certain factors could not be investigated in this study for their impact. Use of contraceptive, particular HAART regimens, history of tuberculosis, nutritional status and drug abuse might affect Candida colonization. Future study to identify Candida species in larger population and drug sensitivity test will be beneficial.

In conclusion, our study demonstrated that HIV-infected subjects had higher chance to be Candida carriers and contained higher numbers of Candida colonization than healthy subjects. In addition, HAART usage reduced colonization by non-albicans species. Because maintaining low Candida counts in this population is important, early HAART administration and appropriate antifungal drugs should be considered in HIV-infected patients.

\section{References}

1. Nittayananta W, Talungchit S, Jaruratanasirikul S, Silpapojakul K, Chayakul P, Nilmanat A, et al. Effects of long-term use of HAART on oral health status of HIV-infected subjects. J Oral Pathol Med. 2010;39:397-406.

2. Ortega KL, Vale DA, Magalhaes MH. Impact of PI and NNRTI HAART-based therapy on oral lesions of Brazilian HIV-infected patients. J Oral Pathol Med. 2009;38:489-94.

3. Low A, Gavriilidis G, Larke N, MR BL, Drouin O, Stover J, et al. Incidence of Opportunistic Infections and the Impact of Antiretrovi- 
ral Therapy Among HIV-Infected Adults in Low- and Middle-Income Countries: A Systematic Review and Meta-analysis. Clin Infect Dis. 2016;62:1595-603.

4. Diz Dios P, Scully C. Antiretroviral therapy: effects on orofacial health and health care. Oral Dis. 2014;20:136-45.

5. Navazesh M, Mulligan R, Karim R, Mack WJ, Ram S, Seirawan $\mathrm{H}$, et al. Effect of HAART on salivary gland function in the Women's Interagency HIV Study (WIHS). Oral Dis. 2009;15:52-60.

6. Fethi T, Asma J, Amine SM, Amel EB, Taoufik BC, Mohamed C, et al. Effects on immunological and virological outcome of patients using one protease inhibitor or one non-nucleoside reverse transcriptase inhibitor in a triple antiretroviral therapy: normal clinical practice versus clinical trial findings. Curr HIV Res. 2005;3:271-6.

7. Bartlett JA, Fath MJ, Demasi R, Hermes A, Quinn J, Mondou E, et al. An updated systematic overview of triple combination therapy in antiretroviral-naive HIV-infected adults. AIDS. 2006;20:2051-64.

8. Li YY, Chen WY, Li X, Li HB, Li HQ, Wang L, et al. Asymptomatic oral yeast carriage and antifungal susceptibility profile of HIV-infected patients in Kunming, Yunnan Province of China. BMC Infect Dis. 2013;13:46.

9. Thanyasrisung P, Kesakomol P, Pipattanagovit P, Youngnak-Piboonratanakit $\mathrm{P}$, Pitiphat $\mathrm{W}$, Matangkasombut $\mathrm{O}$. Oral Candida carriage and immune status in Thai human immunodeficiency virus-infected individuals. J Med Microbiol. 2014;63:753-9.

10. Delgado AC, de Jesus Pedro R, Aoki FH, Resende MR, Trabasso $\mathrm{P}$, Colombo AL, et al. Clinical and microbiological assessment of patients with a long-term diagnosis of human immunodeficiency virus infection and Candida oral colonization. Clin Microbiol Infect. 2009;15:364-71.

11. Hung CC, Yang YL, Lauderdale TL, McDonald LC, Hsiao CF, Cheng $\mathrm{HH}$, et al. Colonization of human immunodeficiency virus-infected outpatients in Taiwan with Candida species. J Clin Microbiol. 2005;43:1600-3.

12. Wu CJ, Lee HC, Yang YL, Chang CM, Chen HT, Lin CC, et al. Oropharyngeal yeast colonization in HIV-infected outpatients in southern Taiwan: CD4 count, efavirenz therapy and intravenous drug use matter. Clin Microbiol Infect. 2012;18:485-90.

13. Owotade FJ, Patel M, Ralephenya TR, Vergotine G. Oral Candida colonization in HIV-positive women: associated factors and changes following antiretroviral therapy. J Med Microbiol. 2013;62:126-32.

14. Paula SB, Morey AT, Santos JP, Santos PM, Gameiro DG, Kerbauy $\mathrm{G}$, et al. Oral Candida colonization in HIV-infected patients in Londrina-PR, Brazil: antifungal susceptibility and virulence factors. J Infect Dev Ctries. 2015;9:1350-9.

15. Ribeiro Ribeiro AL, de Alencar Menezes TO, de Melo Alves-Junior S, de Menezes SA, Marques-da-Silva SH, Rosario Vallinoto AC. Oral carriage of Candida species in HIV-infected patients during highly active antiretroviral therapy (HAART) in Belem, Brazil. Oral Surg Oral Med Oral Pathol Oral Radiol. 2015;120:29-33.

16. Borg-von Zepelin M, Meyer I, Thomssen R, Wurzner R, Sanglard $\mathrm{D}$, Telenti A, et al. HIV-Protease inhibitors reduce cell adherence of Candida albicans strains by inhibition of yeast secreted aspartic proteases. J Invest Dermatol. 1999;113:747-51.

17. Cassone A, Tacconelli E, De Bernardis F, Tumbarello M, Torosantucci A, Chiani P, et al. Antiretroviral therapy with protease inhibitors has an early, immune reconstitution-independent beneficial effect on Candida virulence and oral candidiasis in human immunodeficiency virus-infected subjects. J Infect Dis. 2002;185:188-95.

18. Rao KV, Chitturi RT, Kattappagari KK, Kantheti LP, Poosarla C, Baddam VR. Impact of highly active antiretroviral therapy on oral manifestations of patients with human immunodeficiency virus/acquired immuno deficiency syndrome in South India. Indian J Sex Transm Dis. 2015;36:35-9.

19. Satyakiran GV, Bavle RM, Alexander G, Rao S, Venugopal R, Hosthor SS. A relationship between CD4 count and oral manifestations of human immunodeficiency virus-infected patients on highly active antiretroviral therapy in urban population. J Oral Maxillofac Pathol. 2016;20:419-26.

20. Batavia AS, Secours R, Espinosa P, Jean Juste MA, Severe P, Pape
JW, et al. Diagnosis of HIV-Associated Oral Lesions in Relation to Early versus Delayed Antiretroviral Therapy: Results from the CIPRA HT001 Trial. PLoS One. 2016;11:e0150656.

21. Vacharotayangul P, Rungsiyanont S, Lam-Ubol A, Pankam T, Rodbamrung P, Naorungroj S, et al. Higher prevalence of oral human papillomavirus infection in HIV-positive than HIV-negative Thai men and women. Cancer Epidemiol. 2015;39:917-22.

22. Navazesh M, Mulligan R, Barron Y, Redford M, Greenspan D, Alves $\mathrm{M}$, et al. A 4-year longitudinal evaluation of xerostomia and salivary gland hypofunction in the Women's Interagency HIV Study participants. Oral Surg Oral Med Oral Pathol Oral Radiol Endod. 2003;95:693-8.

23. Silverberg MJ, Gore ME, French AL, Gandhi M, Glesby MJ, Kovacs A, et al. Prevalence of clinical symptoms associated with highly active antiretroviral therapy in the Women's Interagency HIV Study. Clin Infect Dis. 2004;39:717-24.

24. Kumar JV, Baghirath PV, Naishadham PP, Suneetha S, Suneetha L, Sreedevi P. Relationship of long-term highly active antiretroviral therapy on salivary flow rate and CD4 Count among HIV-infected patients. J Oral Maxillofac Pathol. 2015;19:58-63.

25. Owotade FJ, Patel M. Virulence of oral Candida isolated from HIV-positive women with oral candidiasis and asymptomatic carriers. Oral Surg Oral Med Oral Pathol Oral Radiol. 2014;118:455-60.

26. Mushi MF, Mtemisika CI, Bader O, Bii C, Mirambo MM, Gross U, et al. High Oral Carriage of Non-albicans Candida spp. among HIV-infected individuals. Int J Infect Dis. 2016;49:185-8.

27. Dos Santos Abrantes PM, McArthur CP, Africa CW. Multi-drug resistant oral Candida species isolated from HIV-positive patients in South Africa and Cameroon. Diagn Microbiol Infect Dis. 2014;79:222-7. 28. Pappas PG, Kauffman CA, Andes DR, Clancy CJ, Marr KA, Ostrosky-Zeichner L, et al. Executive Summary: Clinical Practice Guideline for the Management of Candidiasis: 2016 Update by the Infectious Diseases Society of America. Clin Infect Dis. 2016;62:409-17. 29. Ferreira AV, Prado CG, Carvalho RR, Dias KS, Dias AL. Candida albicans and non-C. albicans Candida species: comparison of biofilm production and metabolic activity in biofilms, and putative virulence properties of isolates from hospital environments and infections. Mycopathologia. 2013;175:265-72.

30. Jiang L, Yong X, Li R, Peng Y, Liu W, Qin Q, et al. Dynamic analysis of oral Candida carriage, distribution, and antifungal susceptibility in HIV-infected patients during the first year of highly active antiretroviral therapy in Guangxi, China. J Oral Pathol Med. 2014;43:696-703.

\section{Acknowledgements}

The authors would like to thank all participants in the study. Also, we thank Dr. Praphan Phanuphak, Dr. Nittaya Phanuphak and all the staffs at the Thai Red Cross AIDS Research Centre for their support in the collaboration of this work. This study was funded by Faculty of Dentistry, Srinakharinwirot University grant.

\section{Conflicts of Interest}

The authors declare that there is no conflict of interest. 